\title{
Green Belt Biosphere Reserve in the Brazilian City of São Paulo
}

\author{
Rodrigo R. Ramos-Ribeiro
}

Nicolaus Copernicus University, Faculty of Biology and Environmental Protection, Lwowska 1,87-100 Torun, Poland, e-mail: rudge@v.umk.pl

\begin{abstract}
This paper presents an analysis of the São Paulo City Green Belt Biosphere Reserve and its ecological services for the city inhabitants. In 1994 UNESCO recognized the Green Belt of São Paulo in Brazil as a Biosphere Reserve. The data presented in this article were collected through literature review. The result indicates the importance to establish Biospheres Reserves, especially for the big cities.
\end{abstract}

Key words: biosphere reserve, green belt, ecological services, São Paulo.

\section{Introduction}

The ecological services have very important functions for cities, especially for the big ones. The Green Belt Biosphere Reserve on the city of São Paulo, one of the largest cities in Brazil, is an important buffer area for the city.

The Biosphere Reserves sites were established by UNESCO to host a network of areas on the globe with relevant environmental value to humanity. This places constitutes areas of marine and territorial ecosystems, or a combination thereof, which are internationally recognized within the framework of UNESCO's Programme of Man and Biosphere (MAB). The Biosphere Reserves Programme MAB objective to contribute for environmental research and conservation programs to study and improve the relationship between people and their environment to conserve the environment through sustainable use of natural resources.

Local governments spontaneously indicate areas they want to see as a declared Biosphere Reserve and are willing to turn their political will into concrete actions that the purpose is achieved.

With support from the State and from a civil society movement, UNESCO declared on June of 1994, the São Paulo City Green Belt Biosphere Reserve (RBCV) as an integral part of the Atlantic Forest Biosphere Reserve. It extends throughout 39 municipalities including São Paulo
Metropolitan Region. Located in the São Paulo state in Brazil (Fig.1) and inhabited by about 16 million people, according with São Paulo State Forest Institute (IF).

The Mata Atlântica Biosphere Reserve was established in 1992. It covers important portions of the Atlantic Forest of 14 States, including the São Paulo City Green Belt. The remnants of Atlantic Forest (in Portuguese language Mata Atlântica) are associated with relevant secondary forests, this forming a unique ecosystem stretching along a distance of more than $3,000 \mathrm{~km}$ parallel to the coast (Victor 2005).

The São Paulo City Green Belt Biosphere Reserve took two years to be created and is part of the Biosphere Reserve of Atlantic Forest. The main steps establish these biosphere reserve involved the São Paulo State Forest Institute (IF), the Brazilian committee of the MAB, the MAB of UNESCO. With approval of the reserve in 1993 and statement of the reserve in 1994, according with São Paulo State Forest Institute, the campaign involved the main process:

- Mobilization of national and international community;

- 2 years of civil strife;

- 2 cultural shows;

- 150 conferences;

- 150,000 signatures collected;

- Environmental impact statement formulated;

- Insertion in the local and international press. 


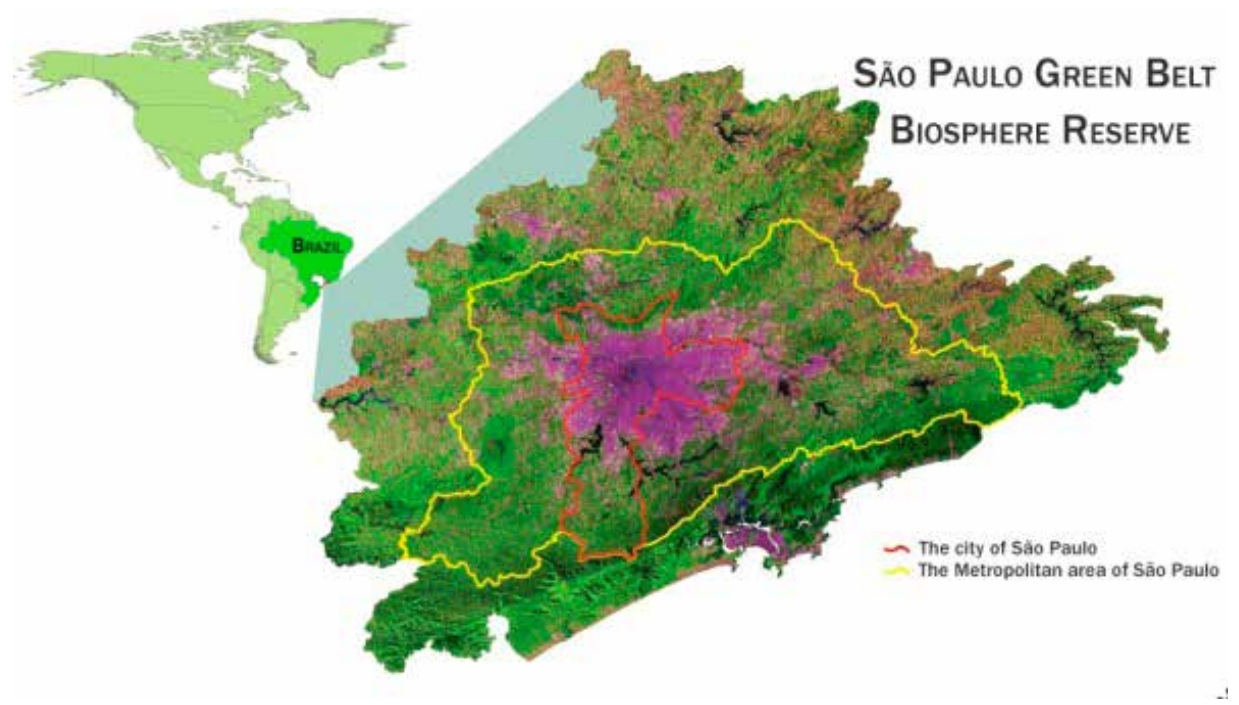

Figure 1. Location of the São Paulo Green Belt Biosphere Reserve in Brazil.

Source: Adapt from São Paulo State Forest Institute

The São Paulo City Green Belt Biosphere Reserve is currently coordinated by the Forest Institute (IF) from the Department of Environment of the State of São Paulo. There are over 600,000 ha of forests and other Atlantic Forest ecosystems at the Reserve, one of the planet's most threatened biomes. In addition to a spectacular biological diversity, the Green Belt of the City of São Paulo ecosystems renders valuable ecosystem services.

\section{Methodology}

The research was done by qualitative analysis with field observation in loco made by the author. The method consists of a bibliographic review of the literature about Biospheres Reserves of UNESCO and the ecological services provided for the city of São Paulo. It had been considered the concept of ecosystem services as the benefits provided by nature for the humans.

\section{Analysis of the study area}

The study area the São Paulo Green Belt Reserve, located in the Southern-East of Brazil (Fig. 2). The biodiversity represents important environmental services of natural assets like land, water and air (Victor 2005).

The city of São Paulo is the largest city in Brazil with 10 percent of the Brazilian population. One of the largest city in the America of Southern hemisphere and the world's seventh largest city by population (according to IF). The green areas constitute a very important benefit for the sustainability of the city (Pereira 2008; Margalef 2005).
The biosphere reserve of the Green Belt in São Paulo covers important places e.g. areas of terrestrial, inner urban, marine and vegetation (IF; Victor 2011).

Conservation movements in Brazil started in the beginning of this century. The first acts of preservation of the Atlantic Forest began at governmental level. For example, the forests covering the headwaters, which supplies water for São Paulo metropolitan area is protected (Junior 2004). In the last couple of years the level of deforestation in Brazil is decreasing but on the other hand protected areas are raising, as a result of a big effort of the country that tries to stop the deforestation. The analysis of data deforestation indicates that it is still happing, but in a very low level, less than 1 percent since from 1999 through 2013. From the total of the deforestation, 22 per cent occurred in the districts surrounding of the Serra da Cantareira (mountain range to the north of the city of São Paulo), which demonstrates the great pressure experienced by the region in that decade.

According with Millennium Ecosystem Assessment (MA), the main drivers of ecosystem change partially assessed are: urban growth, environmental pollution, solid wastes, mining, land regulation, infrastructure development and deforestation.

Between 1991 and 2000, the population of the metropolitan area rose by 58 per cent, at a 5 per cent annual rate. The Figure 3 gives on example of the urban pressure on the Green Belt area and its impact on the landscape (Aquino 2005).

According to the report, between the years of 1991 to 2000 a loss of 6 per cent of the green area of the city of São Paulo was recorded, corresponding to 5,345 ha. The Figure 4 illustrates the deforestations process in the metropolitan area of São Paulo, since the first settlers appeared. 


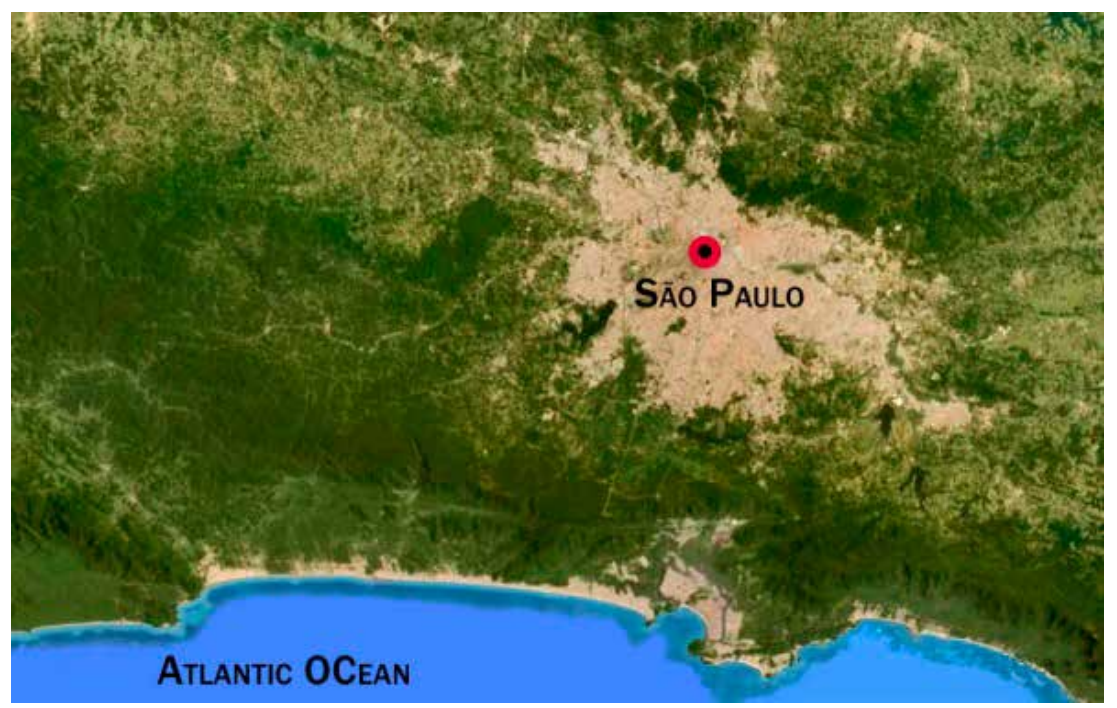

Figure 2. Satellite view from the Brazilian region of the São Paulo. Source: Adapt from googlearth map

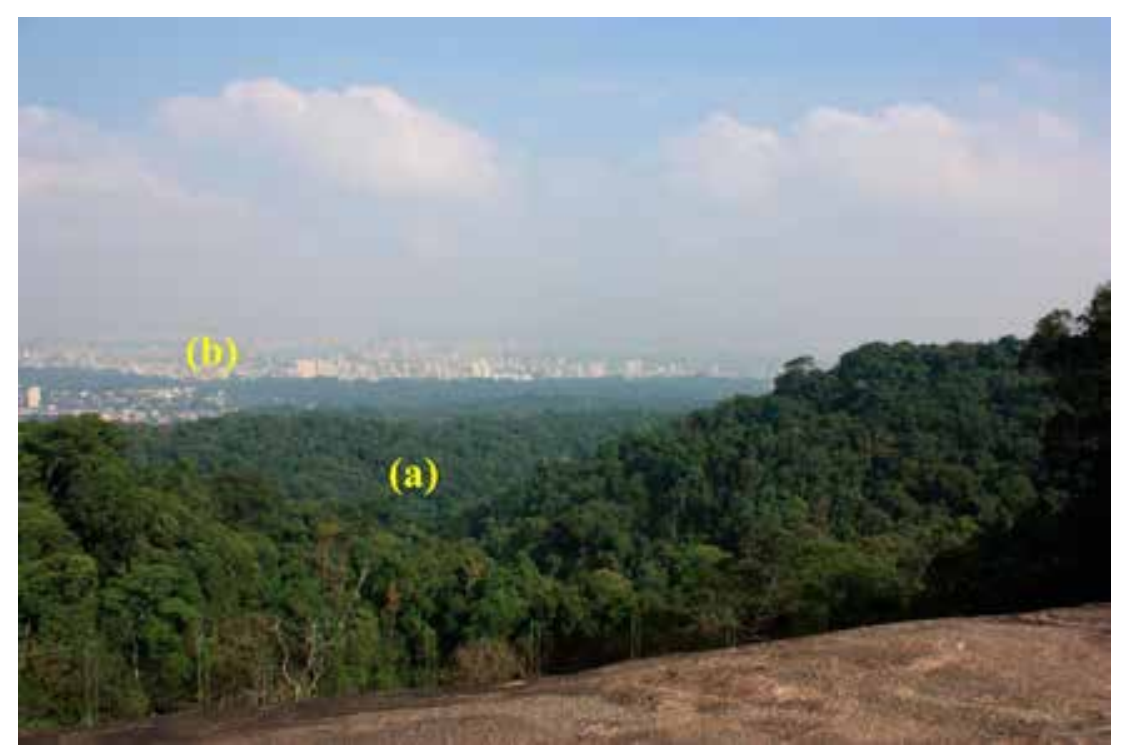

Figure 3. View of the Atlantic forest (a) and urban area (b) from the São Paulo Green Belt Biosphere Reserve. Source: fieldwork; photo by Rodrigo Ribeiro

The urbanization, fires and logging has caused land cover change and lead to yearly losses of important forest areas.

The report of the IPCC in 2013 with scenarios of climate change indicates that area of the city of São Paulo is considered as one that should suffer increase of rains and changes of the temperature up to $4.8^{\circ} \mathrm{C}$ (IPCC 2013).

According with the São Paulo State Forest Institute, the São Paulo Green Belt Reserve is responsible for the quality of life of the city of São Paulo, featuring main benefits, such as:
- Water supply for the city and the headwaters and tributaries of rivers;

- Stabilization of the climate;

- Air quality;

- Biodiversity of species;

- Protection of the vulnerable areas of soils;

- Social use;

- Food security;

- Cultural heritage;

- Potential for new scientific discoveries;

- Encourages self-sustaining activities. 


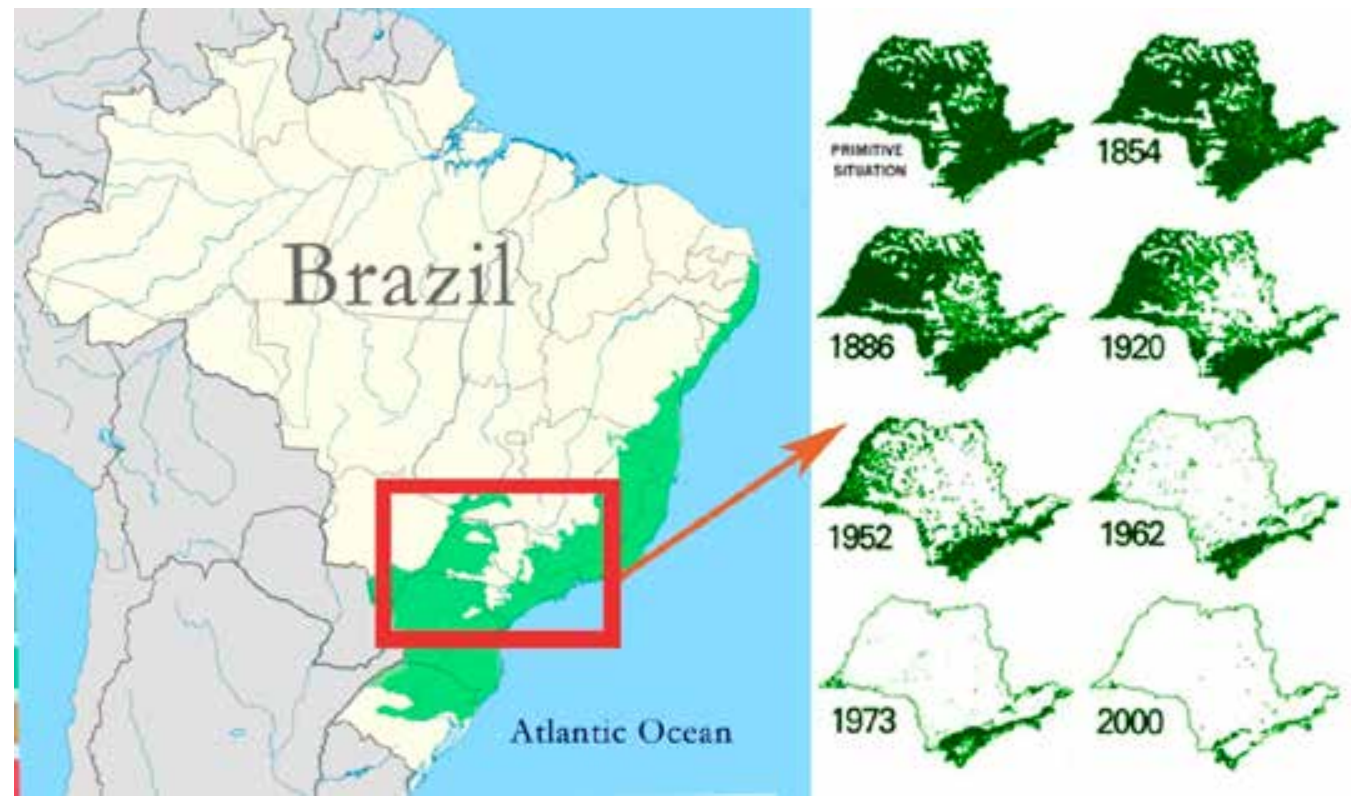

Figure 4. The biome of Mata Atlântica (green area) and the deforestation in the history in the state of São Paulo. Source: Adapt from Política Estadual de Mudanças Climáticas (2009)

\subsection{Urban growth in the city of São Paulo}

Between the year of 1991 and 2000, the population of the metropolitan region increased by 16 percent in absolute numbers. The growth in the past decade confirms the magnitude and aggravation of the housing issue, portraying with precision the surrounds areas of growth in São Paulo's metropolitan region. Consequently, the environment is subjected to a devastating degree of degradation owing to illegal land and occupation of protected areas and vulnerable land.

The main environment problems in the city of São Paulo are air and water pollution. The main air pollutants found in the urban and industrial atmosphere is a result of human influence. There are several categories of substances that may contaminate water, including solid suspensions, organic and toxic substances, heavy metals, herbicides or detergents.

There are 39 municipalities that form the São Paulo metropolitan region registered a daily collection of approximately 83 thousand tons of solid domestic residue (according with Brazilian Institute of Geography and Statistics), which was disposed in twelve sanitary landfills, five controlled landfills and seven large waste dumps. Additionally, an enormous volume of waste material from building construction is produced daily.

\section{Conclusions}

The creation of the biosphere reserve gives a great opportunity for the integrated management of its cities and ecosystems. The biosphere reserves in urban areas can be powerful tool to ensure governance of ecosystem services towards human well-being.

The nomination of the São Paulo Green Belt Biosphere Reserve consists of few main steps. The reserve area of Green Belt in São Paulo is an important buffer area for the city. It is a complex system containing of: forests, protected areas, river basins and water resources, crop lands, coastal and marine ecosystems, cultural heritage, cities and people living together and interacting with each other.

The São Paulo City Green Belt Biosphere Reserve may represent a good reference point for comparisons of ecosystem services in different interacting systems such as urban areas and forests.

In the context of grooving cities and climate change, the biosphere reserves are very important for the local habitants. It promotes protection of the forest ecosystem remnants and the biodiversity; develop of sustainable uses and social practices. The climate regulation provided by the Green Belt is very important in a context of increasing urban pressure and the scenarios of increase of temperature for São Paulo.

In the Polish the region of Kujawsko-Pomorskie (situated in mid-northern Poland), the metropolitan area of 'BiT city' which comprises two big cities: Bydgoszcz (with 360,000 inhabitants) and Torun (with almost 204,000) 
both surrounded by a large forest complex (called Puszcza Bydgoska). This example is a good object for research project with case studies on biosphere reserves. On the other hand, the largest Biosphere Reserve in Poland, the Tuchola Forest, is a good object to carry out comparative studies of large forest areas and urban areas between Brazil and Poland. Studies analysing functions of the Biosphere Reserve as perception of environment quality and ecosystem services could be carried out within the framework of interdisciplinary international research projects.

\section{Acknowledgements}

The author acknowledges the valuable comments for the manuscript provided by Ewa Żukrowska. Also thanks for a friendly supervision of Professor Dr Adam Czarnecki from Nicolaus Copernicus University (UMK) in Poland.

\section{References}

Aquino, V., 2012, Significados da paisagem: celebração do centenário de nascimento de Francisco de Sales Marques Corrêa. University of São Paulo (USP), INMOD, Institute of Fashion, São Paulo.

Brazilian Institute of Geography and Statistics (IBGE), http:/www.ibge.gov.br/home/estatistica/populacao/ condicaodevida/pnsb/lixo_coletado/lixo_coletado110. shtm, [Accessed 25/11/2014].

IPCC, 2013, Working Group I Contribution to the IPCC Fifth Assessment Report Climate Change 2013: The Physical Science Basis, Final Draft Underlying Scientific-Technical Assessment.
Junior E. M., 2004, Deforestation and preservation and of the forest in the State of São Paulo, Brazil. Revista Cientifica Eletrônica de Engenharia Florestal, no. 3 .

Margalef R., 2005, Ecology, Publication Omega, Barcelona.

Millennium Ecosystem Assessment (MA), http://www. unep.org/maweb/en/SGA.Brazil.aspx, [Accessed 25/11/2014].

Pereira J. V. I., 2008, A gestão e o design numa perpectiva sustentável: o caso do mobiliário, Thesis of Master at the University of Aveiro, Aveiro - Portugal.

Política Estadual de Mudanças Climáticas (PEMC), 2009, Plano Participativo de Adaptação às Mudanças Climáticas, http://www.cetesb.sp.gov.br, [Accessed 20.02.2014].

Victor R., 2005, Brazil - São Paulo Greenbelt, http:// www.unep.org/maweb/en/SGA.Brazil.aspx, [Accessed 20.02.2014].

Victor R., 2011, São Paulo City Green Belt Biosphere Reserve: A Platform for Integrated Sustainable Land Management, http://d3n8a8pro7vhmx.cloudfront.net/ greenbelt/pages/261/attachments/original/1380902950/ rodrigo_victor_sao_paulo_green_belt_biosphere_ res_17075.pdf?1380902950, [Accessed 20.02.2014].

São Paulo State Forest Institute (IF), Reserva da Biosfera do Cinturão Verde da Cidade de São Paulo, State of São Paulo, http://iflorestal.sp.gov.br/o-instituto/rbcv/ocinturao-verde/, [Accessed 20.02.2014].

UNESCO Biosphere Reserves, Ecological Sciences for Sustainable Development, http://www.unesco.org/new/ en/natural-sciences/environment/ecological-sciences/ biosphere-reserves/, [Accessed 23.02.2014].

UNESCO, São Paulo city Green Belt Biosphere Reserve, 2003, http://www.unesco.org/mab/urban/urbandocs. htm, [Accessed 23.02.2014]. 